\title{
Animal rights or welfare?
}

SIR - In the leading article "Animal rights nonsense" (Nature 13 October, p.562), your writer seeks to destroy the concept of animal rights, but appears to have a distorted idea of what philosophical theories of rights actually entail. He seems to believe that espousal of animal rights necessarily means the belief that animals have a diverse set of absolute and inalienable rights. In fact, very few rights theorists (notably some pacifists) would claim that this is true even of human beings. Few, for example, would deny that other humans have a general right not to be tortured; equally, few would deny society the right to use torture to reveal the site of an atomic bomb beneath London. Professor Bernard Rollin expresses the theory of animal rights succinctly, "if one takes the position that the right to life is not absolute in the case of humans, but that strong moral reasons must be given in defence of any violation of that right, one must take a similar position vis-à-vis animals".

This kind of principle does not mean that in a genuine conflict of serious interests one is not entitled to hold that (generally speaking) a human life is more valuable than that of a non-human animal. It does mean that the animal's rights ought not to be infringed for frivolous, trivial or avoidable reasons. I personally believe that temporary pleasure of the palate, vanity, commercial profit and the cure of readily preventable or minor illness represent such unacceptable reasons.

Your writer's second premise, that only those with duties can have rights, would not appeal to most defenders of human rights, as it clearly rules out rights for mentally-ill, severely retarded or very young humans. I doubt whether any civil rights campaigners would accept his view that subordinates can expect no rights unless they comply with all rules laid down by those in authority, however arbitrary. If, however, he really means the sort of tacit agreements which enable us to live together without violent conflict, surely the dog passes this test with flying colours. Dogs may not reliably sit on command, but at least your staff member was not bitten during his experiment in animal responsibility.

Comparison of animals and children eliminates the objection that, if animals have rights, these must be identical to those of adult humans. Most of us would agree that young children have rights, but this does not mean that we consider them competent to refuse life-saving treatment, one of the rights of adult humans. Clearly the same holds good for animals.

Finally, he argues that concern should be given to animal welfare, not rights. The trouble with this attitude is that it is then all to easy to see reforms in our treatment of animals as optional extras, acceptable if they do not cost very much, and even more acceptable if they actually benefit us in the long-run anyway. The language of rights is important because it makes the point that it is obligatory for us to treat animals as objects of moral concern.

48 Gwydir Street,

ROSEMARY RODD

\section{Cambridge CBI $2 L L, U K$}

\section{Clone availability}

SIR - A recent News and Views article ${ }^{1}$ states that investigators from Cold Spring Harbor and Massachusetts Institute of Technology have not "yet been able to test the transforming genes of chicken and now human B-cell lymphomas" which several colleagues and I have described. According to this article, this is because the cloned genes are "unavailable". The implication is that we have refused to supply these clones. On the contrary, we have supplied the chicken $B l y m-1$ clone to all laboratories (16 as of 20 September) who have requested it since publication of its isolation ${ }^{2}$. Similarly, the newly published ${ }^{3}$ human Blym-1 clone is now available to the scientific community. Neither of these clones has been requested by the investigators or laboratories referred to in your article.

GeOFFrey M. COOPER

\section{Dana-Farber Cancer Institute,}

\section{Boston, Massachusetts 02115, USA}

1. Nature 305, 470 (1983).

2. Goubin, G., Goldman, D.S., Luce, J., Neiman, P.E. \& Cooper, G.M. Nature 302, 114-119 (1983).

Diamund, A., Couper, G.M.. Rirz, J. \& Lane, M.A. Nature 305,113 (1983)

\section{The Yogi in Nature}

SIR - You will surely agree with me that anybody who claims that details of grandunification theories are "available" in some ancient script (albeit, alas, in cryptic form) is a joker. I was rather upset to find an advertisement by a clown like the guru Maharishi Mahesh Yogi in a serious journal such as Nature (8 September). Why was this advertisement, in my opinion a serious corruption of Nature's image, accepted for publication? If it was because advertisements are paid for and pecunia non olet, then Nature has embarked on a dangerous and counterproductive course. (Can we look forward to similar advertisements by scientologists and creationists or for von Dăniken's latest brainwave?)

I fear that you will be used. These clever fanatics will boast on the very fact that some of their lunacies appeared in a respectable scientific journal. That it occurred in an advertisement is for them irrelevant. That is why this type of advertisement should be refused. The guru must be denied the slightest trace of a suggestion of being taken seriously in a scientific journal. An advertisement for an astrologer is out of place in an astronomy or astrophysics journal and similarly, an advertisement of people who use quasi-scientific terminology to give their dogmas an air of scientific legitimacy is out of place in Nature.

E. J. ZUIDERWIJK

European Southern Observatory, Casilla 16317, Santiago 9, Chile

\section{Hepatitis B vaccine}

SIR - We would like to re-establish the truth concerning our company's policy on the production of hepatitis B vaccine (Nature 304, 297; 1983). Our production process calls for the sole use of HB-Enegative plasma. No plasma of whatever geographical origin has ever been used in the production of HEVAC $B$ without passing the HB-E-negative control. Therefore the information given about Institut Pasteur Production's "broken promise" is wrong and is based on false information.

Y. GARNIER (President)

Institut Pasteur Production,

3 bd Raymond Poincaré,

Marnes-la-Coquette, France

\section{Nuclear deterrents}

SIR - The British Government's deliberate vagueness on civil defence planning may well be cause for ridicule but the recent disclosure that there are serious deficiencies in the Home Office computer model for predicting the number of casualties in the event of a nuclear attack (Nature 6 October, p.459) must be cause for concern . These deficiencies when taken together suggest more of a deliberate attempt to minimize casualty estimates than mere incompetence. Perhaps the government does not wish to undermine confidence in the nuclear deterrent by suggesting that if deterrence fails all will be lost.

Your editorial advice to the nurses (and other professional groups) on how best to argue what would be the most probable form of nuclear attack would have been relevant 20 years ago before the deployment of accurate counterforce nuclear weapons. In the 1960 s nuclear weapons were only accurate enough to destroy large targets such as cities but not small protected targets such as missile silos. Nuclear retaliation was invulnerable to attack, so a few nuclear demonstration shots might not have precipitated a fullscale nuclear exchange. But deployment of accurate counterforce weapons, by threatening to destroy the enemy's missiles in their silos, lowers the threshold for nuclear war.

In times of crisis the pressure to strike first will be enormous. Deployment of cruise and Pershing missiles in Europe will tie NATO's strategy of flexible response to the strategy of counterforce. Demonstration shots would bring the card house down.

CRISPIN PHILLIPS

Springbank Cottages,

Polton Road, Lasswade,

Midlothian EHI8 IAF, UK 